\title{
PEMODELAN STRUKTUR BAWAH PERMUKAAN DAERAH SUMBER AIR PANAS SONGGORITI KOTA BATU BERDASARKAN DATA GEOMAGNETIK
}

\author{
Oleh: \\ Dafiqiy Ya'lu Ulin Nuha', Novi Avisena ${ }^{2}$
}

\begin{abstract}
ABSTRAK: Telah dilakukan penelitian dengan metode geomagnetik pada tanggal 26 -27 April 2011 di daerah Songgoriti Kota Batu dengan tujuan untuk mengetahui pola Anomali Magnet Total dan struktur geologi bawah permukaan.

Setelah dilakukan koreksi data yang meliputi koreksi diurnal dan koreksi IGRF maka didapatkan nilai anomali magnet total serta kontinuasi ke atas dan reduksi ke kutub. Selanjutnya dilakukan interpretasi secara kualitatif dan kuantitatif. Interpretasi kuantitatif dilakukan dengan membaca pola kontur anomali magnet lokal dan reduksi ke kutub, sedangkan interpretasi kualitatif dilakukan dengan membuat penampang 2,5 D pada dua lintasan $\mathrm{AB}$ dan $\mathrm{CD}$.

Berdasarkan interpretasi kuantitatif pada kontur anomali magnetik lokal didapatkan variasi nilai anomali antara -800 nT-600 nT dengan anomali tinggi terdapat pada arah timur dan barat daerah penelitian, anomali sedang terletak pada daerah tengah penelitian dan anomali rendah terdapat pada sedikit daerah tengah penelitian. Daerah penelitian didominasi anomali magnetik sedang. Berdasarkan interpretasi kualitatif pada model penampang 2,5 D lintasan $\mathrm{AB}$ dan $\mathrm{CD}$, didapatkan tujuh body yaitu batuan tufa, batuan tufa, batuan breksi vulkanik, batuan breksi tufaan, batuan lava, batuan basalt, dan batuan andesit. Berdasarkan sifat fisik dari tiap lapisan batuan, diduga batuan sarang dalam sistem geothermal yang berupa sumber air panas di daerah penelitian adalah batuan breksi vulkanik dengan batuan penutup (cap rock) berupa batuan tufa.
\end{abstract}

Kata Kunci : Anomali Magnet, Struktur Geologi, Air Panas.

\section{PENDAHULUAN}

Posisi kepulauan Indonesia yang terletak pada pertemuan antara tiga lempeng besar menjadikan wilayah Indonesia memiliki tatanan tektonik yang kompleks. Hai ini ditandai dengan munculnya rangkaian gunung api sehingga Indonesia dengan segala aktivitas tektoniknya dijadikan model konseptual pembentukan panas bumi di Indonesia.

Metode geomagnetik merupakan salah satu metode geofisika yang dapat digunakan untuk survei pendahuluan pada eksplorasi bawah permukaan. Dengan mengetahui struktur geologi bawah permukaan akan sangat membantu dalam penafsiran struktur dasar dan patahan yang mungkin dijadikan jalur keluar fluida-fluida panas bumi. Di daerah yang terdapat potensi panas bumi larutan hidrotermal dapat menimbulkan suatu perubahan sifat kemagnetan batuan. Adapun salah satu perubahan yang terjadi antara lain turun atau hilangnya suatu sifat kemagnetan dari bahan (demagnetisasi). Dengan kondisi tersebut, maka penelitian dengan menggunakan metode magnetik dapat digunakan untuk melokalisir daerah anomali magnet yang diduga memiliki kaitan dengan manifestasi panas bumi yang berupa hidrotermal.

1,2 Jurusan Fisika Fakultas Sains dan Teknologi UIN Maliki Malang 
Berdasarkan hal tersebut peneliti ingin mengetahui pola sebaran anomali magnet total di derah Songgoriti dan juga ingin mengetahui struktur geologi bawah permukaan daerah Songgoriti Kota Batu berdasarkan data geomagnetik.

\section{KAJIAN TEORI}

Dasar teori metode geomagnetik adalah Gaya Coulomb:

$$
F=\frac{m_{1} m_{2}}{r^{2} \mu} r_{1}
$$

Dimana $\mathrm{F}$ adalah gaya yang bekerja diantara dua magnet dengan kuat medan magnet $\mathrm{m}_{1}$ dan $\mathrm{m}_{2}, \mu$ adalah permeabilitas medium yang melingkupi kedua magnet dan $\mathrm{r}$ adalah jarak kedua magnet

Metode Magnetik menganut teori medan potensial. Potensial magnetostatik didefinisikan sebagai tenaga yang diperlukan untuk memindahkan satu satuan kutub magnet dari titik tak terhingga ke suatu titik tertentu dan dapat dituliskan sebagai (Telford,1982:65) :

$$
A(r)=-\int_{\infty}^{r} H(r) d r
$$

Potensial dan medan dari anomali magnetik biasanya didefinisikan sebagai potensial dan medan yang hanya dibangkitkan oleh benda termagnetisasi.

Bila benda magnetik diletakkan dalam medan luar $\mathrm{H}$, kutub-kutub internalnya akan menyearahkan diri dengan $\mathrm{H}$ dan terbentuk suatu medan magnet baru yang besarnya adalah (Kurniati, 2008: 18):

$$
H^{\prime}=4 p k H
$$

Tingkat suatu benda magnetik untuk mampu dimagnetisasi ditentukan oleh suseptibilitas kemagnetan (k), yang dituliskan sebagai (Burger,1992:394) :

$$
\mathrm{I}=\mathrm{kH}
$$

Besaran yang tidak berdimensi ini merupakan parameter dasar yang dipergunakan dalam metode magnetik. Harga $\mathrm{k}$ pada batuan semakin besar apabila dalam batuan tersebut semakin banyak dijumpai mineral-mineral magnet yang bersifat magnetik.

Medan magnet bumi terkarakterisasi oleh parameter fisis yang dapat diukur yaitu arah dan intensitas kemagnetannya. Parameter fisis itu adalah deklinasi magnetik D, intensitas magnetik horizontal $\mathbf{H}$ dan intensitas magnetik vertikal $\mathbf{Z}$.

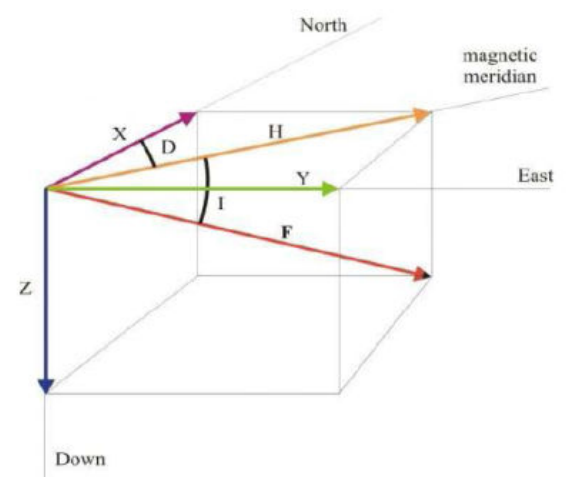

Gambar 1. Elemen Medan Magnet Bumi

Created with 
Dari elemen-elemen ini, semua parameter medan magnet lainnya dapat dihitung. Deklinasi $\mathbf{D}$ adalah sudut antara utara magnetik dengan utara geografis, inklinasi $\mathbf{I}$ adalah sudut antara bidang horizontal dan vektor medan magnetik total $\mathbf{F}$, besar sudut diukur dalam derajat. Medan Magnet bumi terdiri dari tiga bagian yaitu medan utama, medan luar, dan anomali medan magnetik. Anomali magnetik merupakan target survei. Adanya anomali magnetik menyebabkan perubahan dalam medan magnet total bumi dan dapat dituliskan sebagai:

$$
H_{T}=H_{M}+H_{A}
$$

Dengan $\mathrm{H}_{\mathrm{T}}$ adalah medan magnet total bumi, $\mathrm{H}_{\mathrm{M}}$ adalah medan magnet utama bumi dan $\mathrm{H}_{\mathrm{A}}$ adalah medan anomali magnetik.

Daerah Batu dan sekitarnya termasuk dalam pegunungan dan perbukitan vulkanik berupa perbukitan kuarter. Batuan yang mendominasi daerah ini adalah tuf batu apung, tuf pasiran, tuf breksi. Batuan Gunungapi Kuarter Tengah (Qpv-kb,r,b) merupakan endapan piroklastik bersusun andesit dan basal. Batuan Gunungapi Arjuno-Welirang (Qvaw) dan Batuan Gunungapi Tengger (Qvt), terdiri atas breksi, tufa, lava dan breksi tufaan. Tufa Malang (Qvtm) dan Tufa Rabano (Qvtr) merupakan endapan yang bahannya dari gunungapi kuarter disekitarnya, umumnya terdiri dari tufa. Batuan Gunungapi Kuarter Atas (Batuan Gunungapi Penanggungan/Qvn dan Batuan Gunungapi Panderman/Qvp) merupakan batuan yang bersusunan andesit (S.Santoso,1986:18-19).

Daerah Songgoriti di dominasi oleh hasil vulkanik dari Gunung Kawi-Panderman terutama batuan lava andesit dan piroklas dengan beberapa terobosan kubah andesit muda yang memotong terus ke timur. Daerah Songgoriti Batu berbatasan langsung dengan batuan basal dan andesit yang lebih tua dari G.Anjasmoro. Bagian timur laut berbatasan dengan daerah lava panas dan breksi batuan gunung api yang lebih tua yang dihasilkan oleh Gunung Arjuno-Welirang. Sebuah singkapan lapisan tipis abu vulkanis batu apung muncul ke permukaan bumi. Sebelah selatan Songgoriti dan sampai utara hamparan andesit Gunung Anjasmoro yang diyakini mula-mula berasal dari lubang kawah Gunung Kembar dalam kompleks Gunung Arjuno-Welirang.

Daerah songgoriti memiliki jenis batuan gunung api Penanggungan (Qv-n) dan batuan gunung api Panderman (Qv-p) di permukaan di dominasi oleh sebaran tufa, breksi tufaan, aglomerat, lava, breksi vulkanik, dan tanah pelapukan dari breksi gunung api dan breksi tufaan umumnya lanau pasiran berkerikil dan lempung pasiran. 


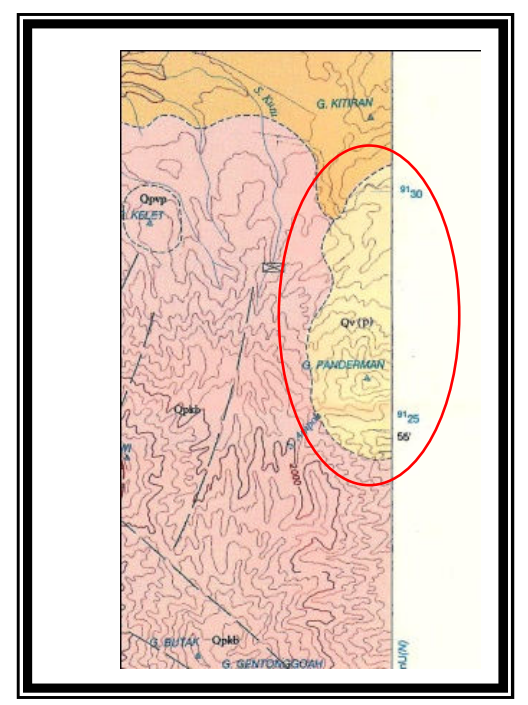

Gambar 2. Peta Geologi Daerah Penelitian

\section{METODE PENELITIAN}

\section{A. Waktu dan Tempat Penelitian}

Proses pengambilan data dilaksanakan pada tanggal 26-27 April 2011 bertempat di sekitar sumber air panas Songgoriti Kota Batu.

\section{B. Alat dan Bahan}

Alat dan bahan yang digunakan adalam Magnetometer jenis PPM, GPS, Kompas, Peta Geologi, Peta Songgoriti, dan software untuk pengolahan data.

\section{Data Penelitian}

Data-data yang diambil pada penelitian ini antara lain waktu (jam, menit, detik), koordinat lintang dan bujur, ketinggian titik ukur, dan data geomagnetik. (medan total, variasi harian, IGRF).

\section{Prosedur Pelaksaan Penelitian}

Prosedur pelaksanaan penelitian meliputi akuisisi data, pengolahan data, dan interpretasi data. Proses akuisisi data dilakukan di daerah Songgoriti Batu yang terletak pada koordinat $7,86412^{\circ}-7,86869^{\circ}$ LS dan $112,49070^{\circ}-112,49500^{\circ}$ BT. Luas daerah pengambilan data adalah 300 x 400 meter. Proses pengukuran dilakukan dengan metode loop tertutup.

Proses selanjutnya adalah pengolahan data, adalah segala sesuatu proses yang dilakukan terhadap data lapangan meliputi koreksi-koreksi, konturing dan analisa. Data medan magnetik total hasil pengukuran masih berbaur antara efek dari dalam dan luar bumi. Efek medan magnetik dari luar bumi dihilangkan dengan koreksi diurnal. Koreksi diurnal terhadap data menghasilkan medan magnetik yang hanya berasal dari dalam bumi. Efek medan magnetik utama dari data pengukuran dihilangkan dengan koreksi IGRF. Hasil koreksi IGRF berupa data anoali medan magnetik total. 


\section{HASIL DAN PEMBAHASAN}

Hasil pengolahan data setelah dilakukan koreksi-koreksi (koreksi diurnal dan koreksi IGRF) ditunjukkan pada gambar 3:

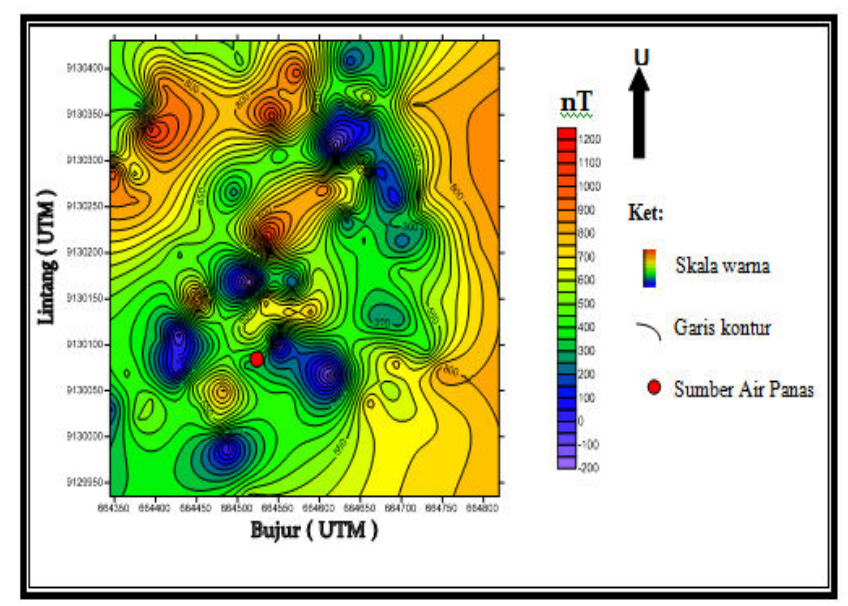

Gambar 3. Kontur Anomali Magnet Total

Nilai anomali magnetik (gambar 3) daerah penelitian dapat dikelompokkan menjadi tiga kelompok anomali, yaitu: anomali magnetik rendah pada skala warna biru sampai ungu dengan nilai kurang dari $200 \mathrm{nT}$. Anomali magnetik sedang pada skala warna kuning sampai hijau dengan nilai $200 \mathrm{nT}$ sampai $700 \mathrm{nT}$. Anomali magnetik tinggi pada skala warna kuning tua sampai merah dengan nilai lebih dari $700 \mathrm{nT}$.

Hasil yang didapatkan setelah dikoreksikan IGRF (anomali magnet total) adalah gabungan antara anomali regional dan anomali lokal. Sehingga perlu dilakukan pemisahan antara kedua anomali tersebut, karena untuk proses interpretasi hanya dilakukan untuk anomali lokal saja. Untuk memisahkan anomali regional dan anomali lokal tersebut maka perlu dilakukan kontinuasi ke atas. Pada pembahasan ini dilakukan kontinuasi ke atas pada ketinggian 100 sampai 600 meter di atas permukaan laut. Hasil kontinuasi ke atas dengan ketinggian 500 meter di atas permukaan laut (gambar 4), anomali regional telah melemah, karena sudah tidak ada pasangan dipole magnetik yang terbentuk pada kontur anomali regional.

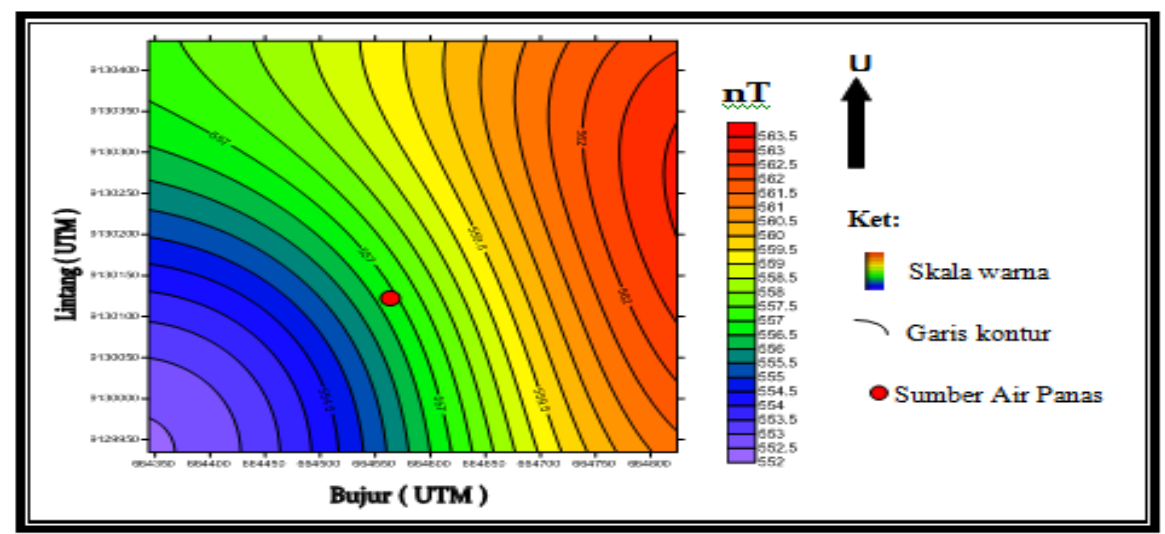

Gambar 4 Kontur Anomali Regional pada Ketinggian 500 mdpl 


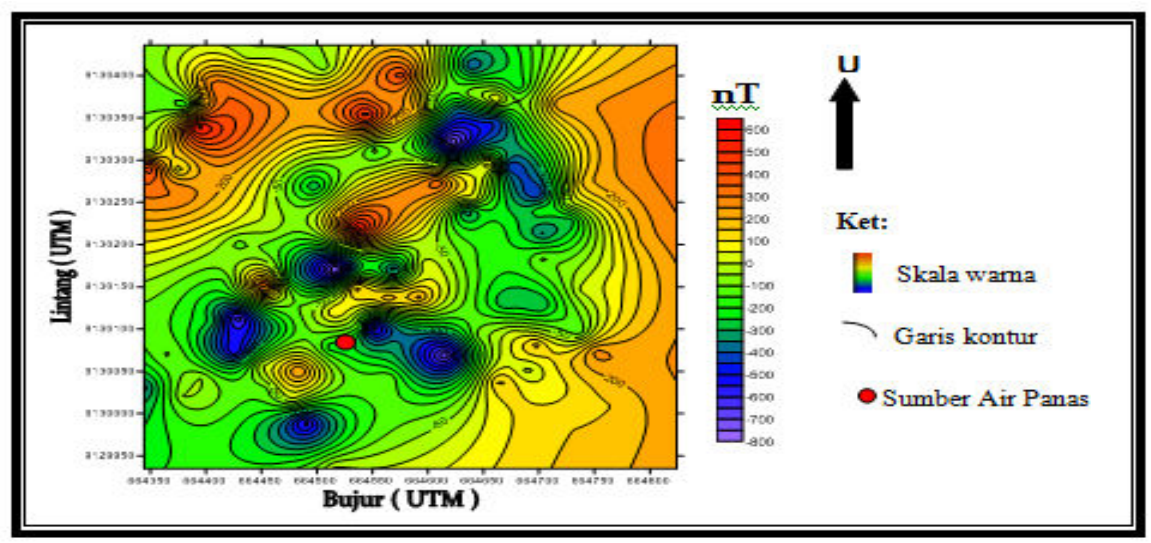

Gambar 5. Kontur Anomali Lokal pada Ketinggian 500 mdpl

Nilai anomali magnetik lokal pada daerah penelitian berada pada kisaran -800 nT sampai 600 nT. Bervariasinya nilai anomali magnetik lokal tersebut disebabkan oleh adanya ketidakseragaman material bawah permukaan pada daerah penelitian. Pada penelitian ini target anomali magnetik yang diharapkan adalah anomali rendah atau sedang karena berkaitan dengan demagnetisasi batuan akibat panas yang dilepaskan dari suatu lapangan daerah manifestasi panas bumi.

Nilai anomali magnetik (gambar 5) daerah penelitian dapat dikelompokkan menjadi tiga kelompok anomali, yaitu: anomali magnetik rendah pada skala warna hijau tua sampai biru dengan nilai kurang dari -300 nT ditafsirkan sebagai batuan vulkanik yang telah mengalami pelapukan tinggi (batuan breksi tufaan dan batuan tufa yang telah lapuk). Anomali magnetik sedang pada skala warna hijau muda sampai kuning dengan nilai -300 nT sampai $300 \mathrm{nT}$ ditafsirkan sebagai respon batuan vulkanik yang telah mengalami pelapukan sedang seperti batuan batuan lava dan batuan andesit yang terlapukkan. Anomali magnetik tinggi pada skala warna kuning tua sampai merah dengan nilai lebih dari 300 nT ditafsirkan sebagai defleksi dari batuan beku atau batuan vulkanik seperti batuan lava andesit yang diperkirakan mempunyai hubungan erat dengan batuan intrusi yang bersifat magnetik sedang sampai tinggi. Berdasarkan tiga kelompok anomali magnet daerah penelitian didominasi oleh nilai anomali magnetik sedang yang tersebar di tengah daerah penelitian yang membujur dari utara ke selatan. Sedangkan anomali magnetik tinggi tersebar pada daerah timur dan barat daerah penelitian yang membujur dari utara ke selatan dan anomali magnetik rendah terdapat hanya sedikit pada daerah tengah penelitian.

Pada survei magnetik, inklinasi vektor kemagnetan baik karena pengaruh induksi ataupun medan dari luar dapat menghasilkan pola dipol pada data magnetik. Oleh karena itu perlu dilakukan suatu proses transformasi reduksi ke kutub yang dapat mentransformasikan vektor kemagnetan tersebut sehingga mempunyai arah vertikal seperti ketika dilakukan pengukuran di kutub. Dengan transformasi reduksi ke kutub ini diharapkan dapat menghasilkan suatu pola anomali magnetik yang bersifat monopol, sehingga dapat memudahkan proses interpretasi karena lebih dapat menggambarkan pola sumber dari anomali magnetik. 


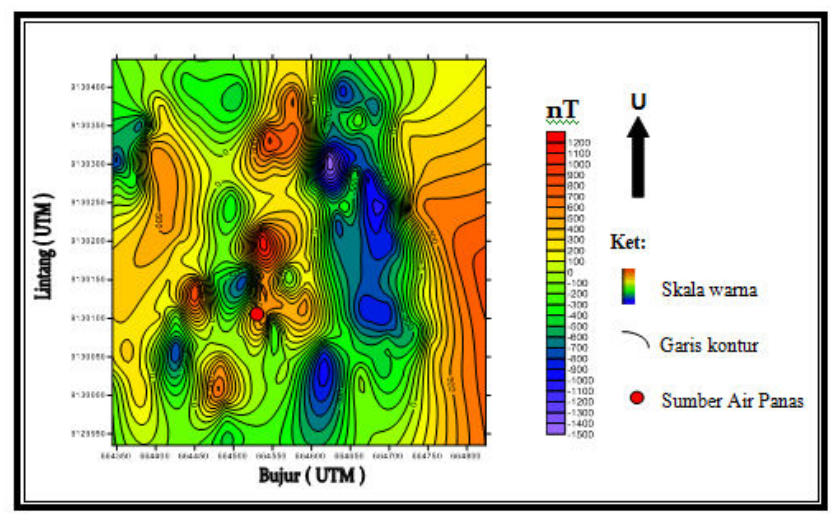

Gambar 6. Kontur Hasil Reduksi ke Kutub

Setelah dilakukan proses reduksi ke kutub didapatkan peta kontur anomali magnetik yang mengalami penguatan nilai kemagnetannya. Hasil analisa dengan menggunakan reduksi ke kutub menghasilkan anomali yang sebenarnya mempunyai nilai suseptibilitas yang rendah. Suseptibilitas yang rendah hanya bisa terjadi jika suatu material magnetik terpanaskan hingga mencapai temperature Curie suatu batuan. Dengan pemanasan tersebut, material magnetik dapat mengalami demagnetisasi. Dengan menggabungkan hasil analisa kontur anomali magnetik lokal dan reduksi ke kutub menunjukkan bahwa daerah sumber air panas Songgoriti terletak pada anomali magnetik tinggi, sementara harga anomali magnetik rendah yang menunjukkan zona demagnetisasi hidrotermal (menurunnya sifat kemagnetan batuan akibat panas) terletak disebelah kanan sumber air panas yang membujur dari utara ke selatan. Sehingga dapat diperkirakan posisi sumber panas bumi ada di sebelah kanan (arah timur daerah penelitian) sumber air panas Songgoriti.

Pemodelan struktur bawah permukaan dilakukan pada dua lintasan irisan penampang melintang yaitu $\mathrm{AB}$ dan $\mathrm{CD}$. Model anomali magnetik lokal pada profil $\mathrm{AB}$ dan CD yang dibuat dengan menggunakan software Mag2 $d c$, dimana parameter inputnya adalah inklinasi, deklinasi dan IGRF (medan magnetik utama bumi). Pada daerah penelitian ini harga inklinasi dan deklinasi berturut-turut $-33,2^{\circ}$ dan $1,4^{\circ}$ dan harga IGRF daerah penelitian $44986,3 \mathrm{nT}$.

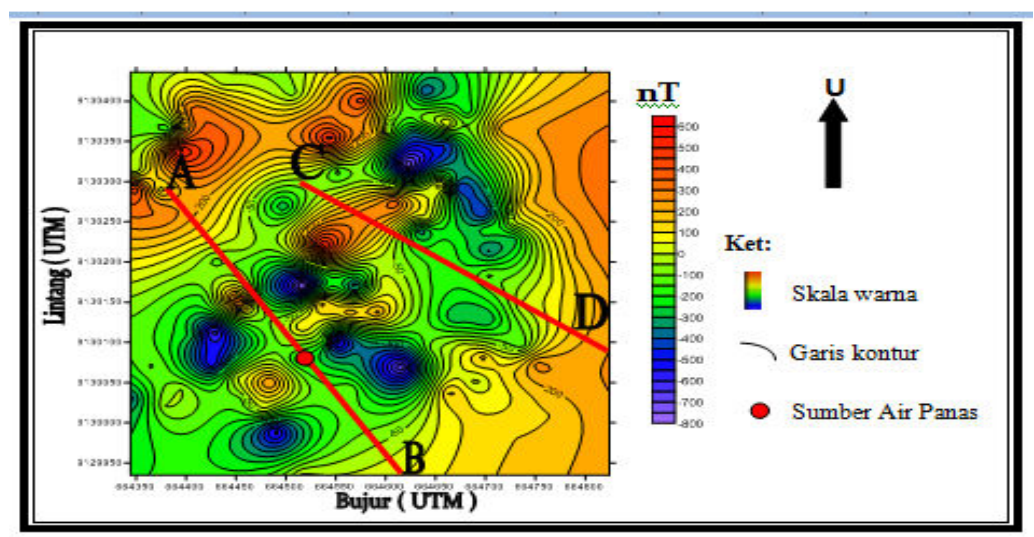

Gambar 7. Irisan Penampang Melintang Lintasan AB dan CD 
Lintasan $\mathrm{AB}$ melintang mulai dari arah barat hingga ke arah tenggara dengan melewati sumber air panas Songgoriti dan beberapa anomali positif dan anomali negatif. Panjang lintasan ini sekitar 409,78597 meter yang terdiri dari 113 titik pengukuran. Lintasan CD melintang mulai dari arah barat hingga ke arah tenggara dengan melewati beberapa anomali positif dan anomali negatif. Panjang lintasan ini sekitar 350,85 meter yang terdiri dari 100 titik pengukuran.

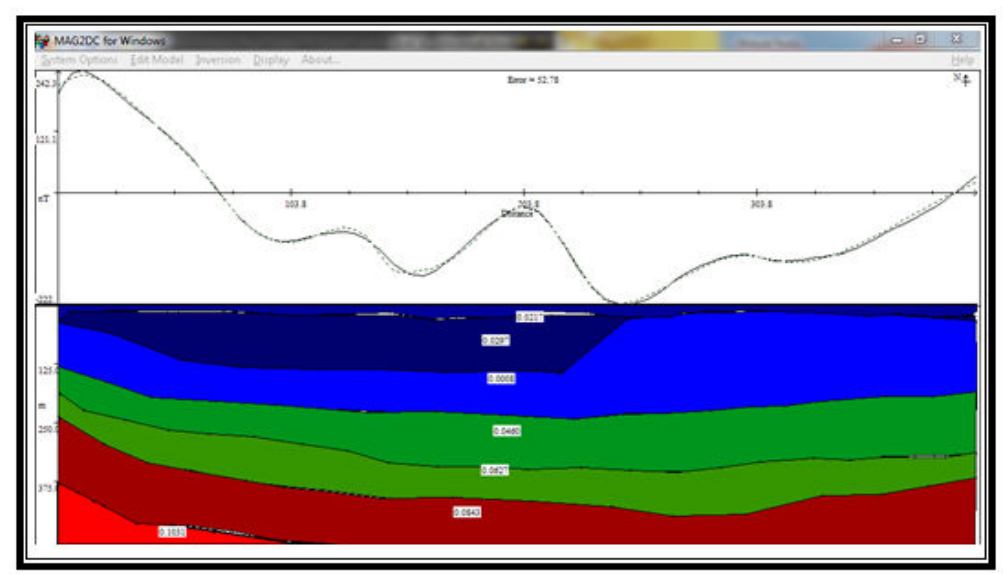

Gambar 8. Model Penampang Anomali Lokal Lintasan AB

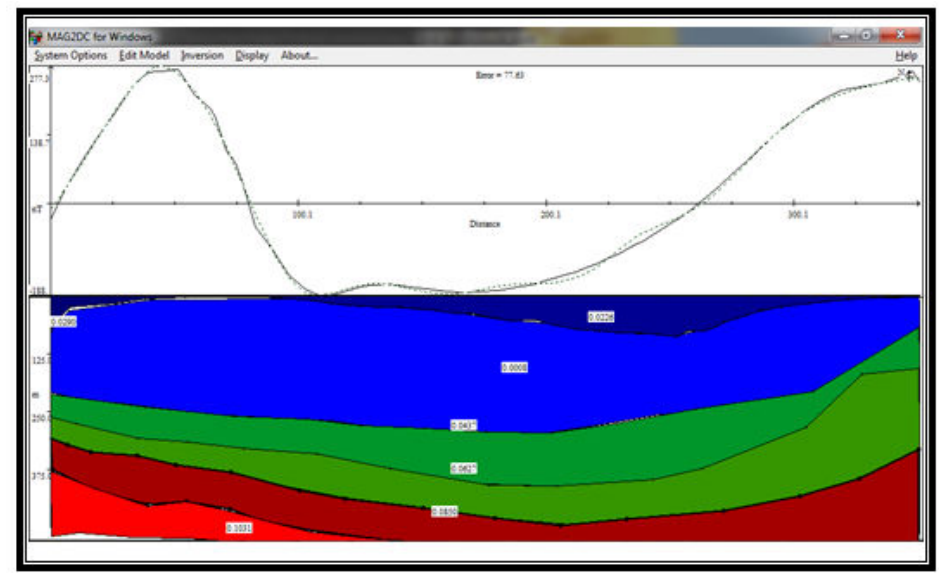

Gambar 9. Model Penampang Anomali Lokal Lintasan CD

Penafsiran litologi batuan pada daerah penelitian didasarkan pada data geologi. Berdasarkan informasi geologi diketahui bahwa daerah penelitian didominasi oleh batuan hasil erupsi gunungapi kuarter atas yaitu batuan yang dihasilkan oleh erupsi gunungapi Panderman (Qv-p) dan Penanggungan (Qv-n). di permukaan didominasi oleh sebaran tufa, breksi tufaan, aglomerat, lava, breksi vulkanik, dan tanah pelapukan dari breksi gunung api dan breksi tufaan umumnya lanau pasiran berkerikil dan lempung pasiran. Terdapat tujuh body pada pemodelan penampang anomali lokal lintasan $\mathrm{AB}$ dan $\mathrm{CD}$.

Pada lapisan pertama dari model lintasan AB diduga merupakan batuan tufa dengan nilai suseptibilitas 0,0217 (dalam SI). Lapisan kedua diduga sebagai batuan tufa dengan suseptibilitas 0,0297 (satuan SI) terletak pada kedalaman 12,75 meter. Lapisan ketiga diduga sebagai batuan breksi vulkanik dengan nilai suseptibilitas 0,0008 (dalam SI) terletak pada kedalaman 13,9442 meter. Lapisan keempat diduga sebagai batuan breksi 
tufaan dengan nilai suseptibilitas 0,0460 (dalam SI) terletak pada kedalaman 130,6275 meter. Lapisan kelima diduga sebagai batuan lava dengan nilai suseptibilitas 0,0660 (dalam SI). Lapisan keenam diduga sebagai batuan basalt dengan nilai suseptibilitas 0,0843 (dalam SI) terletak pada kedalaman 239,0438 meter. Lapisan ketujuh diduga sebagai batuan beku andesit dengan nilai suseptibilitas 0.1031 (dalam SI) terletak pada kedalaman 378,4861 meter. Batuan breksi vulkanik pada lapisan ketiga dengan kedalaman 13,9442 meter ini diduga sebagai batuan sarang, sebagai tempat berkumpulnya fluida (air meteorik) yang telah terpanaskan oleh batuan pemanas, karena batuan breksi vulkanik mempunyai sifat kesarangan yang baik. Selanjutnya tufa pada lapisan kedua dengan kedalaman 12,75 meter diduga sebagai batuan penutup (cap rock), karena sifat dari batuan tufa yang mampat sehingga tidak bisa mengalirkan air atau fluida panas jika tidak ada suatu patahan.

Pada lapisan pertama dari model lintasan CD diduga merupakan batuan tufa dengan nilai suseptibilitas 0,0226 (dalam SI). Lapisan kedua diduga sebagai batuan tufa dengan suseptibilitas 0,0290 (satuan SI) terletak pada kedalaman 1,95 meter. Lapisan ketiga diduga sebagai batuan breksi vulkanik dengan nilai suseptibilitas 0,0008 (dalam SI) terletak pada kedalaman 1,19 meter. Lapisan keempat diduga sebagai batuan breksi tufaan dengan nilai suseptibilitas 0,0437 (dalam SI) terletak pada kedalaman 67,9283 meter. Lapisan kelima diduga sebagai batuan lava dengan nilai suseptibilitas 0,0627 (dalam SI) terletak pada kedalaman 157,3705 meter. Lapisan keenam diduga sebagai batuan basalt dengan nilai suseptibilitas 0,0850 (dalam SI) terletak pada kedalaman 308,3665 meter. Lapisan ketujuh diduga sebagai batuan andesit dengan nilai suseptibilitas 0.1031 (dalam SI) terletak pada kedalaman 379,5650 meter.

Pada penelitian ini batuan pemanas pada sistem panas bumi belum bisa dipastikan apakah berupa kantong magma atau berupa tubuh betuan beku yang besar, namun diduga kuat batuan tersebut berada pada daerah timur laut penelitian, hal ini didasarkan pada anomali rendah di daerah tersebut. Untuk memastikan volume serta kepastian apakah berupa kantong magma atau tubuh batuan beku masih perlu penelitian lebih lanjut, dengan area penelitian yang lebih luas khususnya ke arah timur dan timur laut. Pada penelitian ini tidak ditemukan sesar pada daerah penelitian, hal ini selaras dengan informasi yang terlihat pada peta geologi lembar Kediri, sehingga diduga kenampakan sistem geothermal yang ada, disebabkan oleh rekahan batuan atau rembesan.

\section{KESIMPULAN}

Berdasarkan hasil penelitian geomagnetik dan hasil interpretasi di daerah Songgoriti Kota Batu dapat disimpulkan sebagai berikut:

1. Pola sebaran anomali magnetik total daerah penelitian dapat dikelompokkan menjadi tiga kelompok anomali, yaitu: anomali magnetik rendah dengan nilai kurang dari -300 nT ditafsirkan sebagai batuan vulkanik yang telah mengalami pelapukan tinggi (batuan tufa dan breksi tufaan yang telah lapuk). Anomali magnetik sedang dengan nilai -300 nT sampai $300 \mathrm{nT}$ ditafsirkan sebagai respon 
batuan vulkanik yang telah mengalami pelapukan sedang seperti batuan batuan lava dan batuan andesit yang terlapukkan. Anomali dengan nilai lebih dari $300 \mathrm{nT}$ ditafsirkan sebagai defleksi dari batuan beku atau batuan vulkanik seperti batuan lava andesit. Berdasarkan tiga kelompok anomali magnet daerah penelitian didominasi oleh nilai anomali magnet sedang yang tersebar di tengah daerah penelitian yang membujur dari utara ke selatan.

2. Berdasarkan interpretasi kualitatif pada model penampang lintasan $A B$ dan $C D$, didapatkan 7 body yaitu: batuan tufa, batuan tufa, batuan breksi vulkanik, batuan breksi tufaaan, batuan lava, batuan basalt, dan batuan andesit. Karena batuan breksi vulkanik sangat baik dalam kesarangan, maka batuan ini diduga sebagai batuan sarang fluida yang terpanaskan oleh batuan pemanas, sedangkan batuan batuan tufa diduga sebagai batuan penutup (caprock) dari manifestasi panas bumi daerah Songgoriti.

\section{DAFTAR PUSTAKA}

Blakely, Richard J., 1995. Potential Theory in Gravity and Magnetic Application. New York : Cambridge University Press

Burger, Henry Robert. 1992. Exploration Geophysics of the Shallow Subsurface. New Jersey: Prentice Hall

Kurniati, Asih, Kharisma N., Aulia. 2008. Buku Panduan Workshop Geofisika. Laboratorium Geofisika Jurusan Fisika Fakultas Matematika dan Ilmu Pengetahuan Alam Universitas Brawijaya Malang

Santoso,S. 1986. Geologi Lembar Kediri, Jawa. Bandung: Pusat Penelitian dan Pengembangan Geologi, Direktorat Jenderal Geologi dan Sumberdaya Mineral

Telford W.M, Geldart L.P., dan Sheriff R.E. 1982. Applied Geophysics Second Edition. New York : Cambridge University Press 